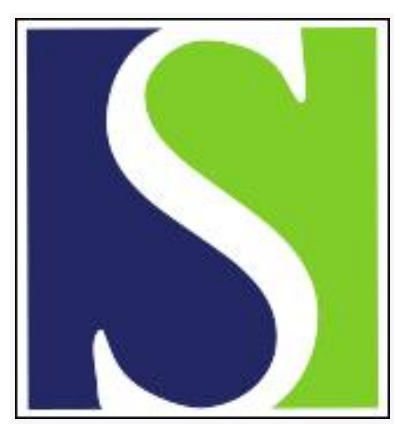

Scand J Work Environ Health 1999;25(6):529-536

https://doi.org/10.5271/sjweh.476

Issue date: Dec 1999

Environmental fertility research at the turn of the century

by Bonde JP

Key terms: environment; fecundity; fertility; human; life-style; occupation; research method; secular trend; toxicity

This article in PubMed: www.ncbi.nlm.nih.gov/pubmed/10884149

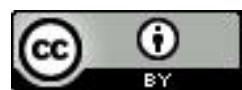




\title{
Environmental fertility research at the turn of the century
}

\author{
by Jens Peter Bonde, MD'
}

\begin{abstract}
Bonde JP. Environmental fertility research at the turn of the century. Scand J Work Environ Health 1999;25(6, special issue):529-536.

Research into environmental causes of impaired human fertility is still immature. Knowledge on the strengths and limitations of several research options, the main sources of bias, the occurrence of infertility and subfecundity in several countries, the patterns of contraceptive behavior, and the distribution of sperm counts at the population level has advanced, but the much-debated questions about temporal and regional trends in fertility and semen quality remain unsettled. Refined biological markers of male fecundity and markers feasible for large-scale studies of female fecundity are needed. The effects of several life-style factors have been characterized successfully, but the detrimental effects of environmental exposures have not. Most studies are either inconclusive or fail to demonstrate any important risks. If comprehensive knowledge on biological mechanisms is a criterion of maturity, epidemiologic and toxicologic fertility research is young. The new millennium will be challenged to determine the role played by the environment in developed countries, wrong exposure time windows, too crude or inappropriate measures of fertility, and overlooked critical exposures.
\end{abstract}

Key terms environment, fecundity, fertility, human, life-style, occupation, research methods, secular trends, toxicity.

The capability of the human race to reproduce is a fundamental aspect of life. Species have been subject to extinction throughout history, and in some cases extinction has been caused by reduced fertility. Fecundity is defined as the biological ability to conceive, to carry the pregnancy to a successful termination, and to raise the offspring to reproductive age (1). Demographers have been studying fertility in populations for many years, but it was not until the last $3-4$ decades of the 20 th century that epidemiologists and toxicologists took interest. One reason was the increasing attention paid 25 years ago to possible links between hazardous exposures and reproductive failures in general. Another was the almost concomitant reporting of severe male reproductive dysfunction in workers who had been exposed to the nematocide dibromochloropropane (DBCP) in California (2) and Israel (3) . These early reports of reduced sperm count in small groups of workers did not adhere to current epidemiologic standards but quickly convinced the scientific community because of the extreme effects, including azoospermia, the independent demonstration of infertility (4-6), and the agreement of human data with animal experimental evidence. Up to that time scientific publications on occupational risk to fertility were very few (7-9). Almost from scratch several groups in the
United States and a few in Europe and other places started out to settle whether the occupational environment constituted an important domain of preventable causes of infertility $(10-22)$. Now 25 years later it is time to ask if the main achievements in the field of observational human fertility research render us able to meet the scientific challenges of the next century. To answer this question, we need to review briefly what we have learned from a methodological and factual point of view, to take the temperature of the maturity of the field at present, to delineate major unsettled scientific questions, and, final$1 \mathrm{y}$, to discuss how to resolve these issues.

\section{What did we learn about human fertility at risk during the past 25 years?}

The severe spermatotoxic effects of DBCP in manufacturing and agricultural workers initiated thoughts that many chemicals in our environment may entail a risk to fertility. The Californian workers did not experience any signs or symptoms of intoxication (2). They were exposed to rather low levels of DBCP in ambient air, and severe oligospermia occurred after a few months in some

1 Department of Occupational Medicine, Århus University Hospital, Århus, Denmark.

Reprint requests to: Dr Jens Peter Bonde, Department of Occupational Medicine, Aarhus University Hospital, Building 02C Nørrebrogade 44, DK 8000 Århus C, Denmark. [E-mail: AKH-JPBON@aaa.dk] 
persons. Men do not talk about infertility. But conversation among wives of workers engaged in DBCP production disclosed the problem. Could it be that many more chemicals have hidden effects on fertility? From the DBCP perspective that seemed to be a sound concern. During the period 1977 to 1999 altogether about 220 original papers on environmental risk to fertility were published in the scientific literature according to a Medline search (table 1). Although many studies report positive associations between an occupational or environmental exposure (including life-style factors) and measures of human fecundity, it is noteworthy that most associations are weak and, with the exception of smoking among women, high alcohol intake of both genders, and a few occupational exposures (radiant heat, chlordecone, ethylenedibromide, ethoxyethanol, and inorganic lead), cannot be considered causal so far $(23,24)$.

The increased interest in environmental fertility research has dramatically increased knowledge on the advantages and limitations of research methodologies, and new approaches for field studies have been developed.

Conventional measures of semen quality, such as sperm count, morphology, and motility, are persistently the most important biological markers of male fecundity (25). Fundamental aspects of semen quality in the general population, such as intra- and interindividual variation, were comprehensively described in a classical series of longitudinal studies on healthy men in the United States (26-29). Important determinants of semen quality, including the period of sexual abstinence, season, radiant heat and effects associated with advancing age, have been characterized in detail. The sperm count increases almost linearly by $5-15$ million per day dur- ing the first 7 days of sexual abstinence, but after 1 week the effect of abstinence levels off completely [(30 and Bonde, unpublished observations]. In the northern hemisphere sperm count is some $20-30 \%$ higher in winter than in late summer $(31-33)$. Age has little impact on sperm count in men less than 50 years of age, but later in life the sperm count declines rapidly (34). Knowledge on these issues is crucially important for the adequate control of bias in analytic epidemiologic studies (35). Semen quality may serve as a sensitive biological marker of testicular function in its own right, but results of recent population-based follow-up studies of the relation between semen quality and the likelihood of pregnancy in a menstrual cycle add to the value of environmental sperm studies (36). It has become evident that sperm count and sperm morphology are rather strong and independent predictors of pregnancy (36). When assumptions about the sperm count distribution in a population are made, it is possible to implement this knowledge to outline scenarios on the impact on fertility resulting from shifts in sperm count (37).

Sperm studies are generally impeded by low response rates, which may be associated with strong selection bias because of the preferential participation of subfecund men (35). If selection is related to exposure, erroneous results are obtained. Recent studies show that this is not a theoretical concern (38). Although semen quality has proved to be a useful measure, it is obvious that more reliable markers that are easier to collect would represent a major achievement. Many efforts have been invested in obtaining objective and reliable analyses of sperm motility with computer-aided methods $(39,40)$, but so far the results have been disappointing since

Table 1. Number of original papers on occupational and environmental risk to human fertility published from 1977 to 1999 according to a Medline search. ${ }^{a}$

\begin{tabular}{|c|c|c|c|c|c|}
\hline \multirow[t]{2}{*}{ Outcome } & \multirow[t]{2}{*}{ Search string ${ }^{b}$} & \multicolumn{3}{|c|}{ Year of publication } & \multirow[t]{2}{*}{ All } \\
\hline & & $1977-1985$ & $1986-1995$ & $1996-1999$ & \\
\hline Fertility rate & (fertility-rate OR birth-rate) AND * & 5 & 8 & 6 & 19 \\
\hline Time to pregnancy & (time-to-pregnancy) AND * & - & 5 & 18 & 23 \\
\hline Semen quality & $\begin{array}{l}\text { (semen [MESH] OR sperm [MESH] OR testis } \\
\text { [MESH] AND * }\end{array}$ & 12 & 29 & 35 & 76 \\
\hline Reproductive hormones & $\begin{array}{l}\text { (sex-hormone [MESH] OR gonadotropins } \\
\text { [MESH] OR LH/blood [MESH] OR FSH/blood } \\
\text { [MESH] OR testosterone/blood [MESH] OR }\end{array}$ & & & & \\
\hline Menstrual cycles & $\begin{array}{l}\text { estradiol/blood [MESH]) AND * } \\
\text { (Menstrual cycle [MESH]) AND * }\end{array}$ & $\begin{array}{l}7 \\
5\end{array}$ & $\begin{array}{c}16 \\
4\end{array}$ & $\begin{array}{l}25 \\
13\end{array}$ & $\begin{array}{l}48 \\
22\end{array}$ \\
\hline Early embryonal loss & (early embryonal loss) AND * & - & 1 & 5 & 6 \\
\hline $\begin{array}{l}\text { Male-mediated } \\
\text { developmental toxicity }\end{array}$ & $\begin{array}{l}\text { (male-mediated OR paternal OR } \\
\text { parental [MESH] OR fathers [MESH]) AND } \\
\text { (pregnancy-outcome OR spontaneous- } \\
\text { abortion OR congenital-malformation OR } \\
\text { cancer OR neoplasm [MESH]) AND * }\end{array}$ & 3 & 5 & 8 & 16 \\
\hline All studies & & 32 & 71 & 110 & 213 \\
\hline
\end{tabular}

a Several publications were deleted by manual check, and the lists were supplemented from the author's files.

$\mathrm{b}^{*}$ (Occupational exposure [MESH] OR environmental expose [MESH] OR adverse effects [MESH] OR smoking OR alcohol OR coffee) AND human [MESH] 1977:1999 [DP]. 
sophisticated measures of sperm motion add little to the prediction of fertility (41 and Bonde, unpublished observations). New assays, such as the sperm chromatin structure assay (SCSA), provide information about fecundity independent of sperm count and sperm morphology, and it is remarkably stable within and between persons (42, 43). Recently it has become possible to measure serum inhibin B $(44,45)$, which is a direct marker of Sertoli cell function. Inhibin B regulates sperm output by negative pituitary feedback through the follicle stimulating hormone (FSH), but it still remains to be demonstrated whether inhibin $\mathrm{B}$ is a more accurate marker of male reproductive function than FSH. Although advances have been made with respect to the proper conduction and interpretation of sperm studies, the discussion on secular and geographic differences in semen quality is a reminder of the deficiencies of semen studies.

The predominance of biological fertility studies addressing environmental toxicity to male fecundity probably reflects the available research methods and not the fact that male fecundity from an environmental point of view is more vulnerable to toxicants than the female genital organs. The lack of biological markers for female fecundity is a major deficit calling for much more attention in the next century. Recent comprehensive studies of female reproductive hormone profiles are important steps towards the development of biomarkers that may prove useful in large-scale studies of environmental impact on ovulation and menstrual function (46-49). From an epidemiologic point of view there is no sharp delineation between infertility and early pregnancy failure since one-third of conceptuses are lost before clinical recognition of the pregnancy (50), and failure of conception and early pregnancy loss may have causes in common. Improved methods for detecting embryonal loss from the 5 th week of conception using specific human chorion gonadotropin (hCG) analysis of consecutive urine specimens collected during part of the menstrual cycle have already proved feasible in large epidemiologic studies (50-53). Emerging reports on the determinants of early pregnancy loss (54) indicate that much new knowledge can be expected from studies in this field.

In the 1980s it was suggested to use the time taken to conceive (time to pregnancy) as an indicator of a couple's fertility (55-57). This idea was soon adopted by other groups and became the most used approach in studies on occupational and environmental impact on couple fertility. Generally the information on the time (or the number of menstrual cycles) taken to conceive from discontinuance of contraception is collected by interview or questionnaire in population samples or samples of pregnant women $(58,59)$. Time to pregnancy is only measurable if a starting point is well defined, but in western European countries about $60-70 \%$ of all pregnancies are planned (60). However, conceptions taking place in spite of contraception or due to irregular use of contraception are factors which may bias comparisons of time to pregnancy between groups (61). A European concerted action on subfecundity and infertility revealed striking differences in time-to-pregnancy distributions across countries spanning from Sweden in the north to Italy in the south (60). The reasons for these differences have not been clarified, but they may have their roots in different sexual behavior and contraceptive practice. On the contrary the time-to-pregnancy distributions of Thai and Inuit women were remarkably in the range of Danish values in spite of the social and cultural differences between these populations $(62,63)$. Several other types of potential bias related to the timing of exposure, sampling, recall, sexual behavior, and confounding have been described and must be controlled if reliable data are to be obtained $(58,59)$. Consistent results in different populations and in different study designs add considerably to the validity of the results. Therefore, it has become evident that tobacco smoking among women - but not among men - reduces the chance of achieving a pregnancy in a menstrual cycle (the fecundability) by some $30 \%$ (64). Since the time-to-pregnancy methodology was described 15 years ago, 23 occupational or environmental time-to-pregnancy studies have been published (table 1). In addition to tobacco smoking, well-established risk factors for female fecundity now include high-level alcohol intake, increasing age above 30 years, first parity, and oral contraception (transient effects). Several associations between environmental exposure and reduced fecundability have been found (table 1), but knowledge is still too scanty to allow definite conclusions as to causality.

\section{Regional and temporal trends of fertility?}

The long-lasting controversy among andrologists about secular trends in semen quality dating back to the 1970 s was renewed in 1992 by the Carlsen et al report (65) on a dramatic global decline of sperm count during the second half of the 19 th century. The strong conclusions that a serious global change in male fecundity had taken place over a short time-span became headlines in the media worldwide, but were not justified by the presented circumstantial data (66-69). Most importantly, it soon became evident that the apparent secular trend could be explained by geographic differences in sperm count (66). The dozens of papers on secular trends of semen quality in various European and American populations which were published in the aftermath of the Carlsen paper have shown conflicting results (70). These reports are based on data from specific regions, and they are not biased by inappropriate comparisons across countries and continents - but they are hampered by several other 
methodological problems. The high variation of average sperm counts and other seminal characteristics found in these studies are often taken as evidence of regional differences in male fecundity. At the present stage of knowledge such conclusions are not justified. It is not appropriate to make crude comparisons of sperm count differences in different studies when it is not possible to adjust for the strong determinants of sperm count, such as period of abstinence, method of sample collection, season, laboratory techniques for sperm counting, and - not the least important - whether or not it is obvious that the compared groups have been recruited and selected in the very same way. In short, it remains a controversy whether secular and regional differences in reported semen values are real. For much the same reasons it is still not settled whether couple fertility has undergone secular changes in some populations. But international studies that benefit from standardized data collection are now appearing and indicate differences in time to pregnancy across several European countries (60). However, we do not know if these findings represent differences in biological fecundity or if they are due to differences in sexual behavior or the use of contraceptives. It was discovered already in the 1970s that the rate of dizygotic twinning was declining by about $20 \%$ in several countries (71). Several studies initiated to find the causes of this well-documented change in fecundity did not provide definite clues to the problem, although tobacco smoking, because of its antiestrogenic effects, may play a role (72). During later years it has become difficult to study twinning rates because of the rapid increasing use of assisted reproduction in the treatment of infertile couples.

The easy access to population registers in entire countries creates possibilities to obtain accurate measures of the sex ratio for huge populations. It is of great interest that the sex ratio has changed during past 50 years in several countries (73). Although the changes are marginal and not of concern per se, it has been suggested that an excess of girls among offspring may be an indicator of reproductive risks $(73,74)$. Improved obstetric services resulting in a higher rate of live births of preterm children may also play a role for the small shifts in the ratio between genders. It is noteworthy that a higher proportion of female offspring has consistently been reported for offspring of persons with a definite exposure to reproductive toxicants (75). The mechanisms by which toxicants may interfere with the sex ratio has not been unraveled, and the problem represents another task to be solved in the forthcoming decades.

\section{Unsettled scientific questions}

There seems at present to be sufficient indications that prenatal life may be of major importance for fecundity in adulthood. It has been demonstrated in rodents that the number of Sertoli cells in the testis at birth determines the sperm output in adult life (76-78). Other studies suggest that exposure during gestation may reduce the number of Sertoli cells at much lower levels than exposure of the fully developed animal (79). The mechanism of action is still unknown, but disruption of the hormonal control of gonadal development has been suggested as a likely mechanism in some cases. This theory calls for a change of the exposure window from adulthood to the prenatal period. Exposure of pregnant women and perhaps children becomes a high priority whether the outcome of interest is male or female fecundity. Therefore there is a need for an entire new generation of studies linking prenatal exposure with fertility in later life. Very few epidemiologic studies of this kind have been published so far. One example is the suggestive effects of smoking during pregnancy, which perhaps impairs both male and female fecundity in the offspring $(80,81)$. Environmental studies focusing on the dietary intake of persistent organochlorines is another example (82). In Sweden ongoing studies are comparing the fertility in fishermen on the Baltic east coast, whose body levels of persistent organochlorines are high because of their intake of polluted fish, with fishermen on the west coast, who have a considerably lower body burden. Similar studies should be conducted in Greenland and the Faeroe Islands, where people have a high intake of marine food contaminated by biomagnified manmade chemicals. The theory that interference with organ growth in fetal life may permanently change organ function - often referred to as the programming theory $(83-85)$ - has achieved considerable interest in cardiovascular epidemiology, but it may as well be of relevance in the field of reproductive epidemiology (86). An ongoing prospective study of 100000 pregnant women in Denmark and Norway takes its starting point in the programming theory, and much more can be expected to be learned about these issues during the very first decade of the next century.

As chemical exposures in the workplace are reduced in most European countries, it becomes a priority to examine the effects of psychosocial and physical factors. Mental distress may be of importance from a biological point of view because of the links between reproductive hormones and stress hormones. Current knowledge is extremely scanty, but it encourages additional studies $(87-91)$. It has been suggested that research should be initiated in this new field by focusing on effects of extreme stress as a starting point to learn about possible effects of stress in daily life and also in worklife $(92,93)$. Extreme stress situations occur, for example in war situations, in refugees, in people who live through earthquakes (94), and in people who experience severe life events, such as malignant disease or severe traumatic 
injury in children. Studies of effects of stress on fertility must be carried out prospectively since it is well known that infertility itself may be a strong stress factor (91), a fact which at present is a major problem in the interpretation of the results of most studies in this field.

The rapid technological development is diminishing manual work at a high pace, and an ever increasing proportion of the population spends more time in a sitting position in transportation vehicles and office-like surroundings. Therefore it becomes important to determine the extent to which the moderate increase in scrotal temperature associated with the sitting position (95) impairs testicular function and infertility. Moderate testicular heating may not be a problem for men with a high sperm output, but, if testicular function is reduced for other reasons, a modest increase in testicular temperature might be of significance. We have some indications that male drivers are at risk of reduced fecundity $(95,96)$, but more work is needed to quantify the problem and resolve questions about chronicity and the effects on subfertile men.

It is still unknown whether male exposure plays a role in the developmental abnormalities of humans. It has been known for several years that treating male animals with various carcinogens and mutagens before mating may result in a range of disorders in the offspring, for example, malignant neoplasia and congenital malformations (97). The most likely mechanism is damage of germ-line DNA (deoxyribonucleic acid), but epigenetic mechanisms and embryonal exposure by toxic compounds in semen could also be of significance $(97,98)$. The occurrence of male-mediated genetic disorders, for example, some cases of Down's syndrome and retinoblastoma, proves that sperm cells with abnormal hereditary material are able to fertilize. But the strong selection among millions of sperm cells competing for first reaching the ovum may protect against fertilization with abnormal spermatozoa. Earlier studies have found a higher rate of spontaneous abortion in the wives of men with a high proportion of morphologically abnormal sperm, but these findings could not be corroborated in a recent follow-up study of early embryonal loss in first pregnancy planners (unpublished observations). However, this is not the final answer to this important question because sperm chromatin may be abnormal in spite of normal morphology. It is interesting that sperm chromatin abnormalities identified by flow cytometry of acid-denaturated sperm cells is apparently associated with early embryonal loss and spontaneous abortion. The conflicting results of several epidemiologic studies aimed at identifying male-mediated developmental toxicity (99) should not discourage continuing efforts to unravel the male factor in pregnancy failures. The increasing use of immature and possibly highly abnormal sperm cells in advanced in-vitro fertilization techniques emphasizes the need for epidemiologic research. Development of new markers of germ-cell genetic damage feasible for use at the population level may be the key to new insight. Some developments have already been made. Now studies investigating specific chromosome aberrations in sperm cells using the fluorescence in situ hybridization technique (FISH) $(100,101)$ can be expected to appear in the literature in the near future. But automatization of the very labor intensive method, which requires the counting of tens of thousands of cells, is needed before it will be useful in large-scale studies.

Epidemiologic fertility research has strong traditions for links with reproductive toxicology and biology - at least in the environmental and occupational context. The best studies benefit from contributions from all these disciplines. The maturity of a scientific field can be measured by its understanding of biological mechanisms among other things. From this point of view reproductive toxicology and epidemiology are at its very beginning since little is known about the basic mechanisms by which environmental exposures exert their effects.

\section{Concluding remarks}

Considerable advances in epidemiologic fertility research methodology have taken place during the last few decades of the 20th century, but there is still a need to refine the biological markers of male fecundity and to develop new markers that are feasible for large-scale studies of female fecundity. The effects of several life-style factors have been characterized successfully, but knowledge on the detrimental effects of environmental exposures continues to be limited. We are still left with few definite risk factors in this area. The majority of studies are either inconclusive or fail to demonstrate important risks. If a comprehensive understanding of biological mechanisms is taken as a criterion for the maturity of a scientific field, epidemiologic and toxicologic fertility research is young. It is a major challenge for the first decades of the next millennium to settle whether the environment in developed countries plays a modest role in the impairment of fertility or whether the sparsity of findings in environmental studies so far is a result of a focus on the wrong exposure time windows, too crude or inappropriate measures of fertility, or overlooked critical exposures.

\section{References}

1. Kline J, Stein Z, Susser M. Conception to Birth: epidemiology of Prenatal Development. New York (NY): Oxford University Press, 1989. Monographs in epidemiology and biostatistics, volume 14 . 
2. Whorton MD, Krauss RM, Marshall S, Milby TH. Infertility in male pesticide workers. Lancet 1977;2:1259-61.

3. Potashnik G, Ben-Aderet N, Israeli R, Yanai-Inbar I, Sober I. Suppressive effect of 1,2,dibromo-3-chloropropane on human spermatogenesis. Fertil Steril 1978;30:444-7.

4. Levine RJ, Blunden PB, Dalcorso RD, Starr TB, Ross CE. Superiority of reproductive histories to sperm counts in detecting infertility at a dibromochloropropane manufacturing plant. J Occup Med 1983;25:591 - 7.

5. Levine RJ, Symons MJ, Balogh SA, Arndt DM, Kaswandik NT, Gentile JW. A method for monitoring the fertility of workers, 1: method and pilot studies. J Occup Med $1980 ; 22: 781-91$.

6. Levine RJ, Symons MJ, Balogh SA, Milby TH, Whorton MD. A method for monitoring the fertility of workers: 2 . validation of the method among workers exposed to dibromochloropropane. J Occup Med 1981;23:183-8.

7. Lancranjan I, Popescu HI, Gavanescu O, Klepsch I, Serbanescu M. Reproductive ability of workmen occupationally exposed to lead. Arch Environ Health 1975;30:396-401.

8. Procopé B-J. Effect of repeated increase of body temperature on human sperm cells. Int J Androl 1965;10:333-9.

9. Rowley MJ, Leach DR, Warner GA, Heller CG. Effect of graded doses of ionising irradiation on the human testis. Radiation Res 1974;59:665-78.

10. Goldsmith JR, Potashnik G, Israeli R. Reproductive outcomes in families of DBCP-exposed men. Arch Environ Health 1984;39:89-94.

11. Hamill PVV. The epidemiologic assessment of male reproductive hazard from occupational exposure to TDA and TNT J Occup Med 1982;24:985-93.

12. Lamb JC, Warks TA, Gloden BC, Allen JW, Moore JA. Male fertility, sister chromatid exchange, and germ cell toxicity following exposure to mixtures of chlorinated phenoxy acids containing 2,3,7,8-tetrachlorodibenzo-p-Dioxin. J Toxicol Environ Health 1981;8:82-90.

13. Lauwerys R, RoeIs H, Genet P, Toussaint G, Bouckaert A, De Cooman S. Fertility of male workers exposed to mercury vapor or to manganese dust: a questionnaire study. Am J Ind Med 1985;7:171-6.

14. Ratcliffe J, Schrader SM, Steenland K, Clapp DE, Turner T, Hornung RW. Semen quality in papaya workers with long term exposure to ethylene dibromide. $\mathrm{Br} \mathrm{J}$ Ind Med 1987;44:317-26.

15. Ratcliffe JM, Schrader SM, Clapp DE, Halperin WE, Turner TW, Hornung RW. Semen quality in workers exposed to 2 ethoxyethanol. Br J Ind Med 1989;46:399-406.

16. Lipschultz LI, Ross CE, Whorton D, Milby T, Smith R Joyner RE. Dibromochloropropane and its effect on testicular function in man. J Urol 1980;124:464—8.

17. Meyer CR. Semen quality in workers exposed to carbon disulfide compared to a control group from same plant. J Occup Med 1981;23:435-9.

18. Milby TH, Whorton D, Stubbs HA, Ross CE, Joyner R, Lipschultz LI. Testicular function among epichlorohydrin workers, Br J Ind Med 1981;38:372-7.

19. Rachootin P, Olsen J. The risk of infertility and delayed conception associated with exposures in the Danish workplace. J Occup Med 1983;25:394—402.

20. Rosenberg MJ, Wyrobek AJ, Ratcliffe J, Gordon LA, Watchmaker G, Fox SH, et al. Sperm as an indicator of reproductive risk among petroleum refinery workers. $\mathrm{Br} \mathrm{J}$ Ind Med 1985;42:123-127.

21. Wildt K, Eliasson R, Berlin M. Effect of occupational expo- sure to lead on sperm and semen. Reproductive Dev Toxicity Metals 1983;279-300.

22. Wyrobek AJ, Gordon LA, Burkhart JG. An evaluation of human sperm as indicators of chemically induced alterations of spermatogenic function: a report of the US environmental protection agency gene tox program. Mutat Res 1983;115:73-148.

23. Bonde J, Giwercman A. Occupational hazards to male fecundity. Reprod Med Rev 1995;4:59—73.

24. Lähdetie J. Occupation- and exposure-related studies on human sperm. J Occup Environ Med 1995;37:922-30.

25. Rowe PJ, Comhaire FH, Hargreave TB, Mellows HJ. WHO manual for the standardized investigation and diagnosis of the infertile couple. Cambridge (): Cambridge University Press, 1993.

26. Schrader SM, Turner TW, Simon SD. Longitudinal study of semen quality of unexposed workers. Sperm motility characteristics. J Androl 1991;12:126-31.

27. Schrader SM, Turner TW, Simon SD. Longitudinal study of semen quality of unexposed workers: sperm head morphometry. J Androl 1990;11:32-9.

28. Turner TW, Schrader SM, Perez-Pelaez M, Karuhn RF, Van der Ven HH, Jeyendran RS. Morphometric and volumetric comparisons of human spermatozoa. Arch Androl 1989;23:201-6

29. Schrader SM, Turner TW, Breitenstein MJ, Simon SD. Longitudinal study of semen quality of unexposed workers: I. study overview. Reproductive Toxicol 1988;2:183-90.

30. Schwartz D, Laplanche A, Jouannet P, David G. Withinsubject variability of human semen in regard to sperm count, volume and number of spermatozoa and length of abstinence. J Reprod Fertil 1979;57:391-5.

31. Levine RJ, Brown MH, Bell M, Shue F, Greenberg GN, Bordson BL. Air-conditioned environments do not prevent deterioration of human semen quality during the summer. Fertil Steril 1992;57:1075-83.

32. Levine RJ, Mathew RM, Chenault CB, Brown MH, Hurtt $\mathrm{ME}$, Bentley KS, et al. Differences in the quality of semen in outdoor workers during summer and winter. $\mathrm{N}$ Engl J Med 1990;323:12-16.

33. Levine RJ, Bordson BL, Mathew RM, Brown MH, Stanley JM, Starr TB. Deterioration of semen quality during summer in New Orleans. Fertil Steril 1988;49:900-7.

34. Johnson L, Petty CS, Neaves WB. Influence of age on sperm production and testicular weights in men. J Reprod Fertil 1984;70:211-8.

35. Bonde JP, Giwercman A, Ernst E. Identifying environmental risk to male reproductive function by occupational sperm studies: logistics and design options. Occup Environ Med 1996;53:511-9.

36. Bonde JP, Ernst E, Jensen TK, Hjollund NH, Kolstad H, Henriksen TB, et al. Relation between semen quality and fertility: a population-based study of 430 first-pregnancy planners. Lancet 1998;352:1172-7.

37. Bonde JPE, Hjollund NHI, Kolstad HA, Abell A, Larsen SB Environmental semen studies - is infertility increased by a decline in sperm count?. Scand J Work Environ Health 1999;25 suppl 1:12-6.

38. Larsen SB, Abell A, Bonde JP. Selection bias in occupational sperm studies. Am J Epidemiol 1998;147:681-5.

39. Schrader SM, Chapin RE, Clegg ED, Davis RO, Fourcroy JL, Katz DF, et al. Laboratory methods for assessing human semen in epidemiologic studies: a consensus report. Reproductive Toxicol 1992;6:275-8. 
40. Chapin RE, Filler RS, Gulati D, Heindel JJ, Katz DF, Mebus $\mathrm{CA}$, et al. Methods for assessing rat sperm motility. Reproductive Toxicol 1992;6:267-73.

41. Bonde JP, Hjollund NH, Jensen TK, Ernst E, Kolstad H, Henriksen TB, et al. A follow-up study of environmental and biologic determinants of fertility among 430 Danish firstpregnancy planners: design and methods. Reproductive Toxicol 1998;12:19-27.

42. Evenson DP, Jost LK, Baer RK, Turner TW, Schrader SM. Individuality of DNA denaturation patterns in human sperm as Measured by the sperm chromatin structure assay. Reproductive Toxicol 1991;5:115-25.

43. Spano M, Kolstad AH, Larsen SB, Cordelli E, Leter G, Giwercman $\mathrm{A}$, et al. The applicability of the flow cytometric sperm chromatin structure assay in epidemiological studies: Asclepios. Hum Reprod 1998;13:2495-505.

44. Illingworth PJ, Groome NP, Byrd W, Rainey WE, McNeilly AS, Mather JP, et al. Inhibin-B: a likely candidate for the physiologically important form of inhibin in men. $\mathrm{J}$ Clin Endocrinol Metab 1996;81:1321-5.

45. Anawalt BD, Bebb RA, Matsumoto AM, Groome NP, Illingworth PJ, McNeilly AS, et al. Serum inhibin B levels reflect Sertoli cell function in normal men and men with testicular dysfunction. J Clin Endocrinol Metab 1996;81:3341-5.

46. Wright DM, Kesner JS, Schrader SM, Chin NW, Wells VE, Krieg EF. Methods of monitoring menstrual function in field studies: attitudes of working women. Reproductive Toxicol 1992;6:401-9.

47. Kesner JS, Wright DM, Schrader SM, Chin NW, Krieg EF. Methods of monitoring menstrual function in field studies: efficacy of methods. Reproductive Toxicol 1992;6:385-400.

48. Baird DD, McConnaughey DR, Weinberg CR, Musey PI, Collins DC, Kesner JS, et al. Application of a method for estimating day of ovulation using urinary estrogen and progesterone metabolites. Epidemiology 1995;6:547—50.

49. Kesner JS, Knecht EA, Krieg EF, Jr, Wilcox AJ, O'Connor JF. Detecting pre-ovulatory luteinizing hormone surges in urine. Hum Reprod 1998;13:15-21.

50. Wilcox AJ, Weinberg CR, O'Connor JF, Baird DD, Schlatterer JP, Canfield RE, et al. Incidence of early loss of pregnancy. N Engl J Med 1988;319:189—94.

51. Bonde JPE, Hjollund NHI, Jensen TK, Ernst E, Kolstad H, Henriksen TB, et al. A follow-up study of environmental and biological determinants of fertility among 430 Danish first pregnancy planners: Design and methods. Reproductive Toxicol 1998;12:19-27.

52. Eskenazi B, Gold EB, Lasley BL, Samuels SJ, Hammond SK, Wight $S$, et al. Prospective monitoring of early fetal loss and clinical spontaneous abortion among female semiconductor workers. Am J Ind Med 1995;28:833-46.

53. Swan SH, Beaumont JJ, Hammond SK, VonBehren J, Green RS, Hallock MF, et al. Historical cohort study of spontaneous abortion among fabrication workers in the Semiconductor Health Study: agent-level analysis. Am J Ind Med 1995; 28:751-69.

54. Weinberg CR, Moledor E, Baird DD, Wilcox AJ. Is there a seasonal pattern in risk of early pregnancy loss? Epidemiology 1994;5:484—9.

55. Rachootin P, Olsen J. The risk of infertility and delayed conception associated with exposures in the Danish workplace. J Occup Med 1983;25:394-402.

56. Joffe M. Male- and female-mediated reproductive effects of occupation: the use of questionnaire methods. J Occup Med 1989;13:974-9.
57. Baird DD, Wilcox AJ, Weinberg CR. Use of time to pregnancy to study environmental exposures. Am J Epidemiol 1986; $124: 470-9$.

58. Olsen J, Juul S, Basso O. Measuring time to pregnancy: methodological issues to consider. Hum Reprod 1998; 13:1751-3.

59. Olsen J, Skov T. Design options and methodological fallacies in the studies of reproductive failures. Environ Health Perspect 1993;suppl 2:145-52.

60. Juul S, Karmaus W, Olsen J. Regional differences in waiting time to pregnancy: pregnancy-based surveys from Denmark, France, Germany, Italy and Sweden. Hum Reprod 1999; $14: 1250-4$.

61. Baird DD, Weinberg C, Schwingl P, Wilcox AJ. Selection bias associated with contraceptive practice in time-to-pregnancy studies. Ann NY Acad Sci 1995;156-64.

62. Tuntiseranee $P$, Olsen J, Chongsuvivatwong V, Limbutara S. Fecundity in Thai and European regions: results based on waiting time to pregnancy. Hum Reprod 1998;13:471-7.

63. Mai K. Organoklorforbindelsers indflydelse på human fertilitet i Grønland [The impact of organochlorines on human fertility in Greenland: a feasibility study]. Aarhus (Denmark): University of Aarhus, 1997.

64. Bolumar F, Olsen J, Boldsen J, the European Study Group on Infertility and Subfecundity. Smoking reduces fecundity: a European multicenter study on infertility and subfecundity. Am J Epidemiol 1996;143:578—86.

65. Carlsen E, Giwercmann A, Keiding N, Skakkebæk NE. Evidence for decreasing quality of semen during past 50 years. BMJ 1992;305:609-13.

66. Fisch $\mathrm{H}$, Goluboff ET. Geographic variations in sperm counts: a potential cause of bias in studies of semen quality. Fertil Steril 1996:65:1044-6.

67. Olsen G, Bodner K, Ramlow J, Ross C, Lipschultz L. Have sperm counts been reduced 50 percent in 50 years? a statistical model revisited. Fertil Steril 1995;63:887—93.

68. Olsen J. Is human fecundity declining - and does occupational exposures play a role in such a decline if it exists? Scand J Work Environ Health 1994;20 special issue:72-7.

69. Bonde JPE, Kold Jensen T, Brixen Larsen S, Abell A, Scheike T, Hjollund NHI, et al. Year of birth and sperm count in 10 Danish occupational studies. Scand J Work Environ Health 1998:24:407-13.

70. Giwercman A, Bonde JP. Declining male fertility and environmental factors. Endocrinol Metab Clin North Am 1998;27:807-30.

71. Rachootin $\mathbf{P}$, Olsen J. Secular changes in the twinning rate in Denmark 1931 to 1977. Scand J Soc Med 1980;8:89-94.

72. Olsen J, Bonnelykke B, Nielsen J. Tobacco smoking and twinning. Acta Med Scand 1988;224:491-4.

73. James WH. Secular trends in monitors of reproductive hazard. Hum Reprod 1997;12:417-21.

74. Moller H. Trends in sex-ratio, testicular cancer and male reproductive hazards: are they connected? APMIS 1998; 106:232-8.

75. Potashnik G. Dibromochloropropan induced reduction of the sex-ratio in man. Andrologia 1984;16:213-8.

76. Sharpe RM, Skakkebæk NE. Are oestrogens involved in falling sperm counts and disorders of the male reproductive tract? Lancet 1993;341:1392-5.

77. Sharpe RM. Declining sperm counts in men - is there an endocrine cause? J Endocrinol 1993;136:357-60.

78. Sharpe RM. Monitoring of spermatogenesis in man - measurement of Sertoli cell- or germ cell-secreted proteins in se- 
men or blood. Int J Androl 1992;15:201-10.

79. Bjerke DL, Moore RW, Peterson RE. Effects of in utero versus lactational exposure to 2,3,7,8-tetrachlorodibenzo-pdioxin (TCDD) on the male rat reproductive system. Toxicologist 1992;12:80.

80. Ratcliffe JM, Gladen BC, Wilcox AJ, Herbst AL. Does early exposure to maternal smoking affect future fertility in adult males? Reproductive Toxicol 1992;6:297-307.

81. Jensen TK, Henriksen TB, Hjollund NH, Scheike T, Kolstad $\mathrm{H}$, Giwercman A, et al. Adult and prenatal exposures to tobacco smoke as risk indicators of fertility among 430 Danish couples. Am J Epidemiol 1998;148:992-7.

82. Rylander L, Strömberg U, Hagmar L. Dietary intake of fish contaminated with persistent organochlorine compounds in relation to low birthweight. Scand J Work Environ Health 1996;22:260-6.

83. Barker DJ. Intrauterine programming of adult disease. Mol Med Today 1995;1:418-23.

84. Barker DJ. Fetal origins of coronary heart disease. BMJ 1995;311:171-4.

85. Barker DJ, Gluckman PD, Robinson JS. Conference report: fetal origins of adult disease - report of the First International Study Group, Sydney, 29-30 October 1994. Placenta 1995; 16:317-20.

86. Godfrey KM, Barker DJ. Maternal nutrition in relation to fetal and placental growth. Eur J Obstet Gynecol Reprod Biol 1995;61:15-22.

87. Clarke RN, Klock SC, Geoghegan A, Travassos DE. Relationship between psychological stress and semen quality among in- vitro fertilization patients. Hum Reprod 1999; $14: 753-8$

88. Fenster L, Waller K, Chen J, Hubbard AE, Windham GC, Elkin E, et al. Psychological stress in the workplace and menstrual function. Am J Epidemiol 1999;149:127-34.

89. Milad MP, Klock SC, Moses S, Chatterton R. Stress and anxiety do not result in pregnancy wastage. Hum Reprod
1998;13:2296-300

90. Fenster L, Katz DF, Wyrobek AJ, Pieper C, Rempel DM, Oman D, et al. Effects of psychological stress on human semen quality. J Androl 1997;18:194-202.

91. Greil AL. Infertility and psychological distress: a critical review of the literature. Soc Sci Med 1997;45:1679-1704.

92. Olsen J. Design options and sources of bias in time-to-pregnancy studies. Scand J Work Environ Health 1999;25 suppl $1: 5-7$.

93. Hjollund $\mathrm{H}$, reporter. Concluding panel on direction for future research on male reproductive capability. Scand J Work Environ Health 1999,25 suppl 1:76-8.

94. Fukuda M, Fukuda K, Shimizu T, Moller H. Decline in sex ratio at birth after Kobe earthquake. Hum Reprod 1998;13:2321-2.

95. Thonneau P, Bujan L, Multigner L, Mieusset R. Occupational heat exposure and male fertility: a review. Hum Reprod 1998;13:2122-5.

96. Figa-Talamanca I, Cini C, Varricchio GC, et al. Effects of prolonged autovehicle driving on male reproductive function: a study among taxi drivers. Am J Ind Med 1996;30:750-8.

97. Colie CF. Male mediated teratogenesis. Reproductive Toxicol 1993;7:3-9.

98. Wyrobek AJ. Methods and concepts in detecting abnormal reproductive outcomes of paternal origin. Reproductive Toxicol 1993;7:3-16.

99. Olshan AF, Faustman EM. Male-mediated developmental toxicity. Reproductive Toxicol 1993;7:191-202.

100. Wyrobek AJ. Fluorescence in situ hybridization to y chromosomes in decondensed human sperm nuclei. Mol Reprod Dev 1990;27:200-8.

101. Wyrobek AJ, Schrader SM, Perreault SD, Fenster L, Huszar G, Katz DF, et al. Assessment of reproductive disorders and birth defects in communities near hazardous chemical sites, III: guidelines for field studies of male reproductive disorders [see comments]. Reproductive Toxicol 1997;11:243-59. 